\title{
Serving the Jordanian Community through Designing with waste materials (UOP. Design student's up cycling projects as case study)
}

\author{
Asst. Prof. Dr. Mayyadah Fahmi Hussein, Department of Interior Design / University of Petra \\ Teach, Mrs. Sanaa El- Asad, teacher, Department of Graphic Design/ University of Petra \\ Asst. Prof. Dr. Aida Hussein Ahmad Jokhrasha , Department of Graphic Design/ University of Petra
}

\begin{abstract}
This paper was written to address the use of waste materials in the recreation of practical upcycle furniture. And Up cycling has been implemented as one of the methods of environmental protection by making useful items from waste and recycled resources in Jordan. This paper will concentrate on UOP design students, the Faculty of Architecture and Design. Focused to find the ideal use of up-cycle material that could play a role in developing solutions for interesting and interactive furniture design by incorporating a good function into it. The basic purpose of this paper is therefore to give students the opportunity to design items with a potential for widespread social, environmental and economic benefits, and to enhance public understanding of the issues of up-cycle furniture and re-use materials, and then to direct students who wish to explore the issues of recycling and re-use within their own context.

This study was focused on the experimental method and using a descriptive theoretical methodology, the University of Petra Students in two departments (38 students in interior design and 18 students in graphic design) collaborated with instructors to create new works based on waste materials) in three experiments (2011 first and second semesters in interior design and 2016 second semesters in graphic design). The students used fourteen samples from all three studies, from new materials, principles, ideas and works of art that could be used by the Jordanian Community through waste materials design or to create dialogue on the appropriation of images and artefacts for transformational purposes.

There are 14 examples selected to define and evaluate. All the challenges and factors to be considered in the design of up-cycled materials that can be implemented to make better and more productive use of them, especially in interior spaces. Environmental problems in design are also listed as part of the interpretation of the importance of this report.
\end{abstract}

Keywords: Up cycling design, waste materials, serving Jordanian community.

Received: 14.12.2020 Accepted: 21.01.2021 $\quad$ Published: 03.02.2021

\section{INTRODUCTION}

Overuse of Jordanian local resources of upcycle furniture have impacted to many environmental problems, like pollution.

Also with a view to saving natural resources, new goods and furniture could be produced through the process of converting waste materials, and the waste from the manufacturing process is harmful to our health and the environment, and pollution is becoming a major issue in Jordan. However, by using materials or goods to produce another innovative object, the emissions problem could be minimized and at the same time, the sustainability awareness campaign promoted. This also leads to a higher environmental benefit.

Designers are more exposed today in the development of a product to various techniques where machines are no limitations and references are made worldwide from previous technology and inspiration. In providing this waste material to students, concepts can be created first by drawing or mock ups, followed by an understanding of the nature of any waste and eventually, how each material should be used.

Up cycling can be introduced as a "reuse of an object without harming the material it is made from. There was a mistake (Goldsmith, 2012). The method relates to the recreation of materials for recreation or waste materials, which offer them a new life or function without much expenditure on new materials (Brown, 2013). In other words, it will again make old things interesting. This method not only increases the quality of life, but also the environmental benefit of goods that have been invented. (Brown, 2013). 


\section{Problem statement}

Jordan produces 2.2 million tons of urban solid waste per year, increasing by 5 percent annually, of which just 7 percent is recycled or recovered primarily by the informal sector.

Approximately 7000 people (Jordan) are active in informal recycling materials from landfills or around the streets of major cities in the country (Amman) and informal recovery and recycling workshops from smelters to recycling workshops. (https://www.jo.undp.org)

Short product life and packaging are prematurely used for the disposal of valuable capital. Reuse of recycled products is the product of upgraded cycling.

Industrialization, mass manufacturing and world supply chains led to the disparity between people, places, commodities and architecture. There is widespread concern about the consequences of continuing economic growth and resource use (Meadows et al. 2005), including the lack of raw materials (Andreas R. Köhler et al. 2013) and energy, environmental degradation and anthropologic climate change (IPCC, 2014). "Being loved, cared for and used to their very limits until the 19th century, everything in one's possession" (Fromm, 2013).

Furniture is one of the things that causes more pain for disposal. In one side, it does not fit into a standard trash can, nor is it categorized for recycling. But on the other hand, it also represents the

Extending the room. It decides the relationship between users, spaces and each other.

\section{Significant statement}

"Up cycle" is a modern movement in which things have a new life. Under the 3R definition, recycle, minimize and reuse, this pattern focuses on re-use. Moving beyond the known word "Recycle," up-cycle means to place an entity or a substance in a separate cycle. This indicates that the characteristics of the object are enhanced. Also the purpose of the object can be modified to make it attractive and useful again. In this article, we argue that resource effectiveness can lead to the slowing of material flows and to the engagement of design and production projects in waste students, enabling communities to share resources and expertise and providing Jordan with economic benefits.

After reviewing a number of problems directly or indirectly relating to the central concept of up-to-date furniture, we have established an innovative solution. Motivated by educational, economic and social motivations is this revolutionary approach. Objects produced might not have an inherent value as saleable shop products, but they may open a conversation between students and the broader community about the value of the unwanted object and its new profit.

\section{The objective of study}

- Giving design students the opportunity to create products with widespread social, economic and environmental advantages.

- Increase community understanding of the issues of up-cycle furniture and re-use materials by learning more about the types of materials, preservation, functionality, aesthetic value

- To guide students who wish to discuss the issues of recycling and re-use within their own communities.

\section{THERETICAL FRAME WORK}

\section{Sustainability}

In this sense, sustainability is referred to as the process of making something new that has something new.

Minimum long-term impact on the climate (Ainsworth, K.2011). The removal of waste such as wood, used metal or paper, old furniture, bottles, cans and even industrial waste helps to make the livelihood sustainable. Waste is again used where it prolongs the spent life of certain materials and their productivity, the previous function of the original material or furniture becomes an innovative new way to use it. The original kind is preserved or mixed with other items of furniture.

\section{Environmental wise}

The way the earth is maintained is also known as recycling. And cycling is up. However the two strategies are still distinct. Both processes started with raw materials processing and were completed differently. Ride eliminates waste and litter. The products can be replicated, returned in the original shape, and returned as a new resource. The products are regarded as environmentally friendly (Caine, 2010). The disposal of waste from the deposit would only delay in relation to the supply chain above the recycling process. This will subsequently flood our nature with pollution, which stresses the planet and contributes to the greenhouse effect.

During up cycling, the use of raw materials is also reduced as the earth reserves renewable energy sources. Fewer trees are logged and mountainous mining results in less energy use (Caine, 2010). The 
explanation for this is that the mechanism demands that components be used as much as possible because it's an infinite loop. The Cluster 'reduce, recycle, recycle, remove' is the intelligent way of production as it offers the shortest way to reduce the quantity of solid domestic wastes flowing into the waste stream, thereby reducing the world commodity market (Richardson, M. 2011).

\section{Creative approach}

Cycling upstream can be a way to help Mother Earth more creative. It's wonderful to try to preserve the nostalgic value of the product used and to create something new with higher aesthetic qualities instead of throwing it away. Wastes which were previously ignored and overlooked can be found and upgraded to more.

Rosalyn Lazaruk said in terms of interior design that the up-biking approach would make room more personal when there is a creative piece (Ash, A. 2012). This thus suggested that a pleasant, functional design must not contain only 'virgin material (Brown, 2013). The form or type of the source is translated into a new product where the specifications of its new characteristics and space are fulfilled. When the preceding form of the material has been fixed to the table or floor of an indoor room, the hanging on the wall or below the ceiling may be more attractive and desirable after the mixture of original materials or furnishings.

The criteria for experimentation or testing and error methods will not only create and produce modern, inventive, but also rare and unique furniture.

\section{LITERATURE RIVEW}

\section{(Up-cycling service for furniture= AL TALLER, 2014)}

The purpose of this study is to give the old furniture pieces a new excuse. To alter their life cycle so that they are desired again. The designers have an important role to play in assessing the state of the object, interpreting the needs and wishes of the users and finding a creative solution. Silva, R. AL TALLER, 2014).

\section{Appropriation, ephemera and the transformation of waste (2016)}

The basic purpose of this paper is to discuss the effects of the joint project between the University of Hudersfield and Oxfam. Students collaborated with Oxfam, Huddersfield, to produce new works produced from products that Oxfam was unable to market. This was initially seen pedagogically as second year students of the Textiles with Surface Design course engaged in these materials. This study hoped to observe the creation of samples, new materials, concepts, ideas and works of art that could be used to stimulate dialogue on the appropriation of images and artefacts for transformative purposes. (Taylor, M., \& Whitson-Smith, J., 2016).

As part of the Sustainable Architecture Compendium, this educational module on the recycling and reuse of building materials illustrates an interdisciplinary and space-based approach to architectural education. Professors and students are presented with a "blueprint" in the form of four learning units, which include waste reduction, building and demolition recycling, architectural re-use and recovery design.

Each learning unit is further subdivided to expose nested subjects. They are designed to provide interdisciplinary discussions of history and theory, case study examples illustrating the "real-world implementation of theory, and field experiments that allow students to leave the studio and investigate problems within their own societies and regions.

\section{Developing a New Method for the Architectural Design Process: An Experimental Study Using (2018)}

The aim of this study was to attract attention once again in a new form to the 'hands-on' approach. In the design process, several young designers are now using conventional methods and mediums. In this paper the authors present alternate forms of thinking and processes, aside from the use of metaphors, by retaining creativity, fluidity, indeterminacy and waste material flow (as a tool in the conceptual development process).The study results showed that the students were trying to think differently about the items that had been previously ignored. (KhakZand, M., \& Babaei, S., 2018).

\section{METHODOLOGY OF RESEARCH (EXPERMENT WORK)}

The approach for this study included a cross-disciplinary analysis of the literature on waste-related issues. This study was focused on the experimental method accompanied by a descriptive theoretical approach at the Faculty of Architecture and Design in two departments. The first department in 20112012, Department of Interior Design, as part of Basic Design 2 (202102) work in the second semester for Level 1 students and as part of Interior Design 3 (202315) work in the first semester for Level 3 students in 2011-2012. The second department, Graphic Design (203223) Graphic Design Methods, Materials \& 
Equipment (Second Year) 2016-2017, and these two experiments centered on improving furniture and accessories items by using waste products and materials to achieve creative aesthetic and practical value ideas from up-cycle new products.

\section{Describe the Experiments}

Several subjects were explored for the students to generate in this creation process.

The case study project will concentrate on a variety of issues in this creation process. Mainly we're going to talk about up cycling furniture and waste materials. We will also discuss some examples of artisan work in which this work is outlined, giving rise to a whole service offering cultural contexts that are separated between cases providing a wide variety of perspectives.

Students at the University of Petra in two departments (Interior Design and Graphic Design) collaborated with instructors to create differentiated, innovative and special concepts focused on the use of waste materials.

In this research two faculties were founded, interior design and graphic design. The interior design, interior design 3 course was initially completed during the first half of 2011 and students were identified with the project declaration (all in environmental design). The participants were then given a general overview of Jordan's ideal use of sustainable materials and local resources, with examples of architecture in the 3rd course (202212). The students were therefore expected to choose objects based on the objective and imagination of the up-cycled accessory unit taking the link between them and the solution into account.

The student accessories unit has been taken from various natural realms. Overall, students were asked to consider the concept in their minds based on waste materials related to the sustainable restaurant Tal Al roman in Amman as part of the design 3 requirements of the first semester of 2011-2012.

In the second semester of 2011, students of Interior Design took the same basic design 2 (202102) project. The project has taken three weeks to complete. The students used various approaches, using design principles and several different instructions, to arrange and organize up-cycled forms.

The second experiment, which took place in the Graphic Design Department, course (203223) Graphic Design Techniques, Content \& Tool (Second Year) 2016-2017. This course is an introduction to the processes, techniques, materials and equipment used in the development of different types of design applications. Topics include conceptual creation, project design requirements, calculation and handling of design materials, the influence of visual methods and the communicative dimensions of design outcomes. In this assignment, students were asked to build craft by reusing recycled products.

\section{The participants \\ Human participants}

There are two types of participants in these two initiatives. The first project consisted of 18 participants from the Interior Design Program in Design 3, the first semester of 2011 in Design 3. The second project consisted of 20 participants in the 2nd Semester 2011 Basic Design Course. During the two separate years the two projects were directed by one teacher, one teaching assistant and members of the jury, divided into internal jurys (faculty members) and two external jurys (interior designers for the labour market) and 38 students.

Although linked to the second project, 18 participants participated in the Graphic Design Department (203223) Graphic Design Strategies, Content \& Tool 2016-2017. The age of all students in two departments was distributed in two classrooms for each of the two courses between the ages of [18-20].

\section{Instrument participants:}

In the first and second experiments in 2011, the students used the following:

- Three classrooms for realistic courses with reasonable working conditions.

- Several various recycled fabrics and furniture have also been used in these two campaigns.

- 65 white drawing boards with 65 movable chairs were used in all three classes with a white writing board and one desk with two chairs for teachers in each of the three classes.

- Data monitor and screen were used to illustrate various examples of up-cycle furniture and re-use materials in both experiments.

\section{Data Collections}

Data were obtained from books, papers, and websites of scientific journals and the final results of assessments by internal and external jury members of the two studies in three courses in the two departments we mentioned earlier. The target demographic in this research was interior \& graphic design students, educators and interior designers from the labor market. The collection of research 
samples was based on the top seven projects with high evaluations from all years and departments, four designs 3, three simple designs 2 and seven scientific, material \& tool courses.

The data was collected and analyzed to assess the relationship between innovation and the benefits of new up cycling products to save the Jordanian culture.

The researchers have been careful that the data obtained from members of the jury is not $100 \%$ correct, but the researchers have concluded that the result would be similar to the outcome.

\section{THE RESULTS:}

Many of the students noticeably gained confidence during this project, for example, after completing the semester:

* Graphic students benefited from the donation of their projects to one of the government colleges. Department of Graphic Design.

* while the student interior design projects have contributed to other results, including an external exhibition in the Association of Engineers of Architecture and active Business Placement Year applications.

* Visitors to the pop-up exhibition observed that the exhibition displayed a varied body of work on the topic of the re-use of materials ranging from items with a philosophical focus to more decorative and furniture pieces.

* Students were allowed to use any object they found acceptable that, depending on the objects chosen and on the performance of the undertaking, may have the potential to infringe copyright, even though its significance might lie not in its origin, but in its destination.

The results of Upcycled Materials in 14 student's projects:

In these experiments (2011 first and second semester \& 2016 second semester). The students have implemented these following points in their fourteen samples in these three tables below:

Table 1. the results of student's project in first semester 2011/interior design 3. Tal al Roman projects

\begin{tabular}{|c|c|c|c|}
\hline course name and year & $\begin{array}{l}\text { Department } \\
\text { name }\end{array}$ & $\begin{array}{l}\text { Original product } \\
\text { or marital }\end{array}$ & Upcycle Product \\
\hline $\begin{array}{l}\text { Interior design } 3 \\
\text { First project 2011, } \\
\text { (create a green upcycle } \\
\text { lighting unit to the Tal al } \\
\text { roman sustainable } \\
\text { restaurant }\end{array}$ & Interior design & Natural Wood & \\
\hline $\begin{array}{l}\text { Interior design } 3 \\
\text { First project 2011, } \\
\text { (create a green upcycle } \\
\text { lighting unit to the Tal al } \\
\text { roman sustainable } \\
\text { restaurant }\end{array}$ & Interior design & $\begin{array}{l}\text { Natural Wood \& } \\
\text { bamboo }\end{array}$ & Candle natural \\
\hline $\begin{array}{l}\text { Interior design } 3 \\
\text { First project 2011, } \\
\text { (create a green upcycle } \\
\text { lighting unit to the Tal al } \\
\text { roman sustainable } \\
\text { restaurant }\end{array}$ & Interior design & $\begin{array}{l}\text { Natural Wood \& } \\
\text { bamboo }\end{array}$ & lighting unit \\
\hline
\end{tabular}




\begin{tabular}{|l|l|l|l|}
\hline Interior design 3 & Interior design & Tree sticks \\
Burlap \& Natural \\
First project 2011, \\
(create a green upcycle \\
lighting unit to the Tal al \\
roman sustainable \\
restaurant
\end{tabular}

Table 2. the results of student's project in second semester 2011/ basic design 2.

\begin{tabular}{|c|c|c|c|}
\hline $\begin{array}{l}\text { course name and } \\
\text { year }\end{array}$ & $\begin{array}{l}\text { Department } \\
\text { name }\end{array}$ & $\begin{array}{l}\text { Original product } \\
\text { or marital }\end{array}$ & Upcycle Product \\
\hline $\begin{array}{lr}\text { Basic } & \text { design2/ } \\
\text { Petra } & \text { university } \\
\text { second } & \text { semester } \\
2011 & \end{array}$ & Interior design & $\begin{array}{l}\text { Toilet waste roll } \\
\text { carton }\end{array}$ & \\
\hline $\begin{array}{lr}\text { Basic } & \text { design2/ } \\
\text { Petra } & \text { university } \\
\text { second } & \text { semester } \\
2011 & \end{array}$ & Interior design & $\begin{array}{l}\text { Metal wire and } \\
\text { ropes }\end{array}$ & \\
\hline $\begin{array}{lr}\text { Basic } & \text { design2/ } \\
\text { Petra } & \text { university } \\
\text { second } & \text { semester } \\
2011 & \end{array}$ & Interior design & $\begin{array}{l}\text { Left over zippers } \\
\text { with natural wood }\end{array}$ & \\
\hline
\end{tabular}

Table 3. the results of student's project in second semester, Graphic Design Techniques, Material \& Tool (Second Year) 2016-2017

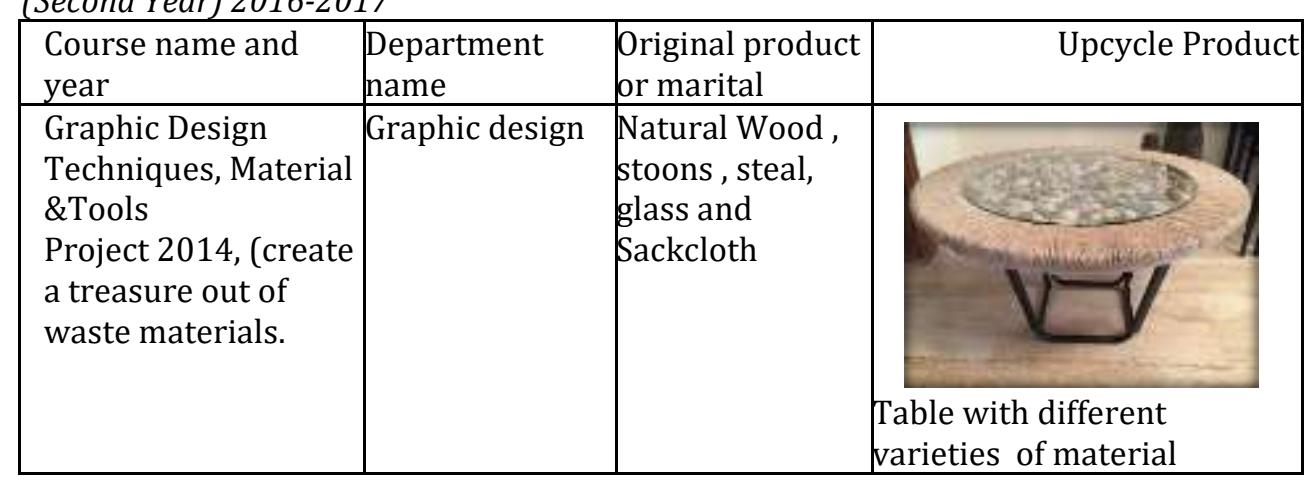




\begin{tabular}{|c|c|c|c|}
\hline $\begin{array}{l}\text { Graphic Design } \\
\text { Techniques, Material } \\
\text { \&Tools }\end{array}$ & Graphic design & $\begin{array}{l}\text { Left over natural } \\
\text { wood from } \\
\text { factory \& } \\
\text { wasting glass }\end{array}$ & $\begin{array}{l}\text { Table from natural wood } \\
\text { and glass }\end{array}$ \\
\hline $\begin{array}{l}\text { Graphic Design } \\
\text { Techniques, Material } \\
\text { \&Tools } \\
\text { First project 2011, } \\
\text { (create a green } \\
\text { upcycle lighting unit } \\
\text { to the Tal al roman } \\
\text { sustainable } \\
\text { restaurant } \\
\end{array}$ & Graphic design & $\begin{array}{l}\text { Natural Wood \& } \\
\text { steel holder }\end{array}$ & natural lighting unit \\
\hline $\begin{array}{l}\text { Graphic Design } \\
\text { Techniques, Material } \\
\text { \&Tools } \\
\text { Petra university } \\
\text { second semester } \\
2015\end{array}$ & Graphic design & $\begin{array}{l}\text { Disposable Tires } \\
\text { covered with } \\
\text { fabric materials } \\
\text { \& glass }\end{array}$ & $\begin{array}{l}\text { Sitting area using ures and } \\
\text { covered with fabric } \\
\text { materials }\end{array}$ \\
\hline $\begin{array}{l}\text { Graphic Design } \\
\text { Techniques, Material } \\
\text { \&Tools } \\
\text { Petra university } \\
\text { second semester. } \\
2015\end{array}$ & Graphic design & $\begin{array}{l}\text { Tire, Sackcloth } \\
\text { Wasting wood } \\
\text { and glazed }\end{array}$ & $\begin{array}{l}\text { Tire covered with } \\
\text { Sackcloth ,wasting wood \& } \\
\text { using on the top glazed }\end{array}$ \\
\hline $\begin{array}{l}\text { Graphic Design } \\
\text { Techniques, Material } \\
\text { \&Tools } \\
\text { Petra university } \\
\text { second semester } \\
2019\end{array}$ & Graphic design & $\begin{array}{l}\text { Wasting wood, } \\
\text { fabric materials }\end{array}$ & Sitting area for out door \\
\hline
\end{tabular}




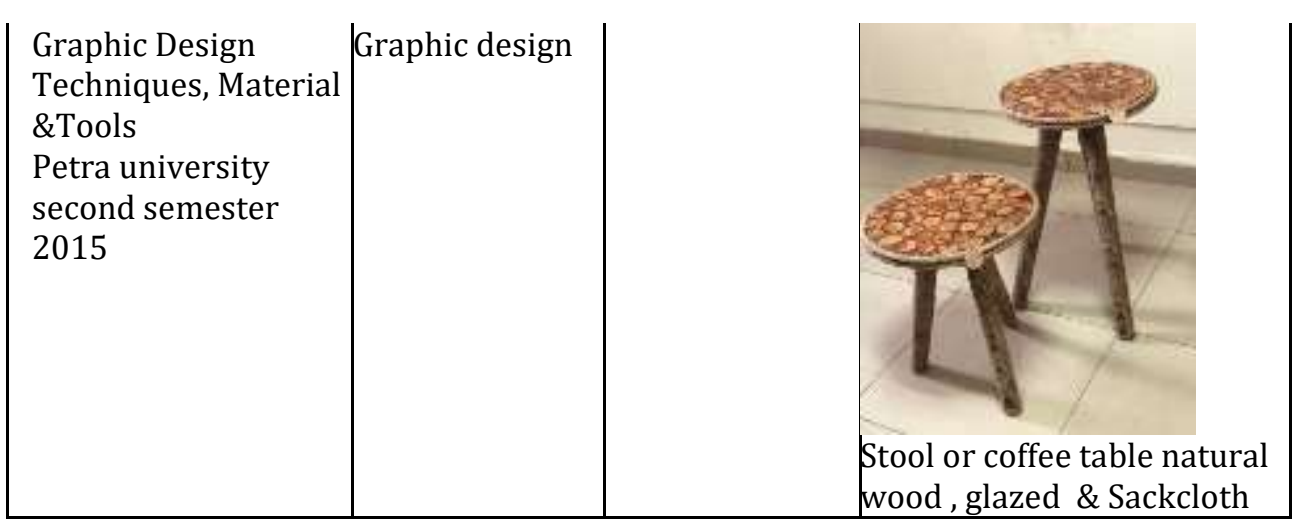

\section{Types of Material}

Understand the essence of the material and how it can be maintained and fit to the space, whether indoor or outdoor, and how it stays. In order to improve them, different types of materials have to be dealt with. The furniture would be raw and pure if the up-cycling material maintained its original colour.

\section{Preservation}

In order to ensure that they are lasting, various types of materials need different preservation methods. Some waste products can require surface processing to prevent bugs or other elements from damaging them. Therefore the essence of the material must be considered, how and what it is to be preserved.

The sort of finish can be added. It is highly advisable for designers to be familiar with the abovementioned products in such a way that their production would have good finishes that can last a long time.

\section{Functionality}

The sky is the limit, every person is able to create a new product with a whole new intent. One thing is to create a new product: a new component is to create a practical product. If a designer can solve a problem and give it a reason to be in space, it will be a bonus.

\section{Aesthetic value}

There are options to get the finished product in place or to have it blended into space. Electricity and the spontaneous placement of furniture or objects in the interior design are now more appreciated by the people as well as use of raw materials with the right creativity which still retains the aesthetic value of a product. These products must then establish the aesthetics of the entire room, giving it a personal sense and character.

\section{Upcycling in Product Design Education.}

The upgrade cycling method provides students with different raw materials to produce creative and imaginative outcomes, thus encouraging their imagined study. It needs students to think from the cage' and from the comfort zone. The conventional philosophy of design requires the artist to research the shape or type of a design. Up cycling, however, facilitates another process of design in which the strengths and capacities of existing materials are studied or fully transformed into a new goal. It helps the designer to take into account and view not only its capacities but also its material potential. The process of up-todate design involves expertise in integrating existing materials into a new and fresh product while fully ignoring and abandoning the original intent of its basic form. When a new life and functionality lease is granted to the products, it has a new impact for space itself.

\section{CONCLUSIONS}

As an up-cycle design, the project centered on transformation, but there was also the opportunity to consider ideas of authenticity and ownership.

Students were allowed to work with and manipulate any item they found acceptable that, depending on the selection and the success of the undertaking, may have the potential to infringe copyright, although this did not happen on that occasion.

Perhaps one significant outcome of the project was to realize that if you look at student projects through the research lens, the outcomes you observed might not be the ones you expected.

In conclusion, the main reasons for this service to be a possible and workable experiment are: 
6.1 Social: the up-cycle projects of these design students are critical for promoting dialogue on the re-use of materials. Where the local community functions more like a small town, there can be a collaborative operation.

6.2 Economically speaking, reuse is cheaper than recycling.

6.3 Ecologically: reuse can be a sustainable habit and it is becoming a trend-Behind the idea of waste, there is a massive market opportunity for raw materials and new purposes-Up cycle as a new trend to reactivate life for these deferential items.

6.4 Up cycling has the ability to incorporate two or more different features into one solid object, making the style very distinctive and unusual.

6.5 Preserved and transformed to a new form is the nostalgic value of current objects. It offers elegance and aesthetic within as its value is increased through the upward cycling phase the original object.

6.6 An up-cycled product will sometimes be a sculpture rather than a product. Rather than its real purpose, the product is seen as a sculpture. It illustrates how successful a product design is as the form exceeds its true objective. The prototype can be used to render this kind of gratitude.

6.7 Integrating and encouraging cycling in product design education will also give designers, but the environment, several benefits.

6.8 Promotes waste-saving among designers and avoids overuse of new raw materials, especially wood.

\section{RECOMANDATION}

Sustainability guidelines should be the foundation for student design courses, since this makes it easier for students to take account of sustainability in design.

It seems that design methodology has no simple law, since design is always regarded as subjective, personal in nature, and dependent on the ingenuity and imagination of the designer.

\section{AKNOLEGMENTS}

The authors would like to thank and express their appreciation for the financial support of the University of Petra for this research in the years 2020-2021. Special thanks should also be given to our great students in both departments (Interior Design and Graphic Design) of the Faculty of Architecture and Design.

\section{REFERENCES}

Brown, 2013 A. Reduce. Reuse. Upcycle. Available:

Goldsmith, B. 2012. Trash or treasure? Upcycling becomes growing green trend. Available:

http://mobile.reuters.com/article/idUSTRE58T3HX20090930?irpc=932 [Accessed on 2013, 14

Ainsworth, K.2011. Sustainability by Design: Creative Collaborations and Sustainable Practice, 2011

(University of New South Wales).

Caine, 2010 T. Recycling vs. Upcycling: What is the difference? Available:

Ash, A. 2012. How to upcycle garage-sale finds, Post media News. Available:

http://www.canada.com/life/greenguide/upcycle\%20garage\%20sale\%20finds/6547293/story.html

Richardson, M. 2011. Design for Reuse: Integrating Upcycling into Industrial Design Practice,

International Conference on Remanufacturing 2011 in Glasgow.

Silva, R. AL TALLER, 2014, up-cycling service for furniture= AL TALLER, Servicio de renovación para mobiliario

Taylor, M., \& Whitson-Smith, J. (2016). Appropriation, ephemera and the transformation of waste. In Futurescan 3: Intersecting Identities. Association of Fashion and Textile Courses.

Bridgens, B., Powell, M., Farmer, G., Walsh, C., Reed, E., Royapoor, M., ... \& Heidrich, O. (2018). Creative upcycling: Reconnecting people, materials and place through making. Journal of Cleaner Production, 189, 145-154

KhakZand, M., \& Babaei, S. (2018). Developing a New Method for the Architectural Design Process: An Experimental Study Using Found-Object Art in the Design Studio. The Design Journal, 21(2), 209-225.

https://www.jo.undp.org/content/jordan/en/home/ourwork/our stories/new-municipal-solid-wasterecovery-and-recycling-contract-improv.html. 2020

http://progressivetimes.wordpress.com/2010/02/17/recycling-vs-upcycling-what-is-thedifference/ http://anitabrowndesignstudio.wordpress.com/2012/09/15/reduce-reuse-upcycle/ [Accessed on [Access on 2013, 17 January], (2010) 17 February.

2013, 15 January], (2012) 15 September.

January], (2012) 30 September.

[Accessed on 2012, 26 December]. 